Article

\title{
Environmental Factors and Intermodal Freight Transportation: Analysis of the Decision Bases in the Case of Spanish Motorways of the Sea
}

\author{
Miguel Ángel López-Navarro \\ Universitat Jaume I, Department of Business Administration and Marketing, Av. Vicent Sos Baynat, \\ Castelló de la Plana 12071, Spain; E-Mail: mlopez@emp.uji.es; Tel.: +34-964-387-113; \\ Fax: +34-964-728-629
}

Received: 12 February 2014; in revised form: 3 March 2014 / Accepted: 12 March 2014 /

Published: 20 March 2014

\begin{abstract}
Today, there is widespread consensus about the notable, yet simultaneously growing, negative environmental impacts generated by the transportation sector. Experts working in a number of different fields consider the current situation to be unsustainable and possible measures to reduce emissions and foster sustainability are being encouraged. The European Commission has highlighted the need to shift away from unimodal road transport toward a greater use of intermodal transport through, for example, motorways of the sea, in light of the evidence that the former makes a significant contribution to increased $\mathrm{CO}_{2}$ emissions. However, although there is a general perception that sea transport is environmentally preferable to road transport, recent studies are beginning to question this assumption. Moreover, little research has been conducted to quantify environmental aspects and incorporate them into the decision-making processes involved in the modal shift. This study first reviews the existing literature to examine the extent to which environmental aspects are relevant in the modal choice in the case of short sea shipping and motorways of the sea. Related to this, the study also evaluates the role that different agents may play in making decisions about choice of mode, taking into consideration environmental aspects. Secondly, we use the values the European Commission provides to calculate external costs for the Marco Polo freight transport project proposals (call 2013) to estimate the environmental costs for several routes (a total of 72), comparing the use of road haulage with the intermodal option that incorporates the Spanish motorways of the sea. The results of this comparative analysis show that the intermodal option is not always the best choice in environmental terms. Consequently, the traditional environmental argument to justify this alternative must be used carefully.
\end{abstract}


Keywords: sustainability; environmental factors; intermodal transport; logistics; short sea shipping; motorways of the sea

\section{Introduction}

Concerns about the environmental impact of transportation are now a relevant issue in the design of sustainable mobility policies and are also attracting a growing interest in academic research (see, for example, [1-6]). Indeed, transportation has been posited as the main threat to the environment in the field of logistics [7,8]. The industry's significant contribution to greenhouse gas (GHG) emissions calls for a modification of current behaviors, involving a shift from mere compliance with environmental regulations to proactive attitudes in companies' environmental strategies [9]. This strategic attitude involves more than achieving higher energy efficiency with the same transport modes, in terms of the resources used and the emissions generated; it also extends to the use, or combination, of alternative modes, namely, intermodality, in order to achieve higher efficiency and greater environmental sustainability.

The literature underlines cost and service as the two main determinants of performance in the field of logistics and transportation [10]. Cost, transit time, reliability and frequency are considered to be the most relevant aspects in deciding which mode to adopt (see, for example, [11,12]). However, very little research has attempted to quantify environmental aspects and incorporate them, as a third significant element, into the decision-making process. Evidence that transportation is responsible for most of the increase in $\mathrm{CO}_{2}$ emissions has, however, led to a growing interest in considering environmental aspects and will undoubtedly attract significant research attention in the near future. This circumstance is especially relevant in modal choice, bearing in mind that the processes of shifting from unimodal road transport to intermodal transportation in any of its variants — by sea or by rail—are often justified by the environmental savings they can generate [13-17].

Within the European context, the Commission's 2011 white paper on transport policies, entitled "Roadmap to a Single European Transport Area-Towards a Competitive and Resource-Efficient Transport System," sets out guidelines for transport policy until the year 2050. It contains interesting details on the future of the freight transport sector, particularly with regard to forthcoming infrastructure and transportation policy priorities of European governments. The document clearly states that the transportation system is unsustainable and needs to be changed, as it cannot continue to develop along its present lines. In the same vein as the previous white paper, published in 2001, intermodal transportation is understood to be crucial, and the integration of different transport modes are seen as a way to ensure sustainable and efficient transport systems. In today's context of increasing exchanges of products and services, the European Union's transportation policy prioritizes railways and short sea shipping (SSS) as complements to road transport, which generates high external costs, both in environmental terms and through traffic congestion, noise, accidents, and so forth. Indeed, the estimated growth in European freight transportation would saturate many road infrastructures if this increase were mainly absorbed by road transport. In the case of Spain, transportation of goods by railway is relatively insignificant, with a market share of less than $4 \%$. In contrast, SSS currently 
appears to be growing in significance, especially through the so-called Motorways of the Sea (MoS). Although today most of the research recognizes environmental impact as an attribute giving sea transport an advantage over road transport, recent studies [18,19] are beginning to question this assumption. In this vein, the need for analysis of the environmental impacts of both modes for specific routes has been highlighted.

In line with the above, in this study we first examine the existing literature to assess the extent to which environmental aspects are relevant in the modal choice in the case of SSS and MoS. In conjunction, we also evaluate the role that different agents may play in making decisions about choice of mode, taking into consideration environmental aspects. Secondly, we use the values the European Commission provides to calculate external costs for the Marco Polo freight transport project proposals (call 2013) to estimate the environmental costs for several routes, comparing the use of road haulage with the intermodal option that incorporates the Spanish motorways of the sea.

\section{The Environmental Impacts of Transportation and the Role of Intermodal Solutions}

The changes in recent decades within the framework of production systems - such as global supply sources, fragmented production chains or just-in-time systems - have resulted in a substantial rise in transportation needs and, in turn, in a significant increase in the environmental impacts it produces [16]. The rise in emissions from transportation since 1990 now make this industry responsible for over $25 \%$ of GHG-related pollution, a figure that seems set to grow further [17,20,21]. In the EU-25, domestic transportation accounts for $21 \%$ of GHG emissions, which have increased by $23 \%$ since 1990 . In this respect, the recently published European Union white paper on transport states quite clearly that the current transportation system is not sustainable and other means need to be developed. Specifically, it points out that "while deeper cuts can be achieved in other sectors of the economy, a reduction of at least $60 \%$ of GHGs by 2050 with respect to 1990 is required from the transport sector, which is a significant and still growing source of GHGs. By 2030, the goal for transport will be to reduce GHG emissions to around 20\% below their 2008 level. Given the substantial increase in transport emissions over the past two decades, this would still put them 8\% above the 1990 level" [17] (p. 3).

Meeting such targets will only be possible by making intense efforts on two different fronts: first, by improving efficiency in each mode, so as to reduce the consumption of resources and the emissions generated, and second, by stimulating the combined use of modes, i.e., intermodal systems, so that the door-to-door transport chain is optimized to make it more efficient and sustainable. Environmental benefits are put forward as a fundamental argument in defending the need to use intermodal systems rather than just road transport [13-17]. Nevertheless, little research has included environmental aspects in the decision-making processes designed to improve performance in logistics and transportation [10]. This remains the case despite the fact that the choice of both the mode of transport and the operating carrier are decisions that have a notable effect on environmental outcomes [22]. Recent research, however, points to a growth in demand from shippers for sustainable transport services [2,22].

Intermodal freight transport has grown significantly in recent years and is destined to play a significant role in the future [23-26]. By combining the advantages of each mode, intermodal transport enables the system to be more efficient, cost-effective and sustainable [27]. Intermodal solutions have been highlighted as one of sustainable transportation options that logistics service providers can offer 
their clients $[22,28]$. In general, the literature reports considerably lower levels of emissions from rail and sea transportation than from road transport [29-31]. Apart from rationalizing the transport logistics chain, intermodal transportation also reduces energy consumption, encourages a more rational use of infrastructures, and lowers environmental impact by taking advantage of the large capacity of sea and rail transport, while also benefiting from the greater flexibility offered by road transport. Despite the unequal growth of the different modes of transport, which has led to the current situation where road transport predominates in the transportation of goods, the European Commission acknowledges that, for short distances, no other alternative means of transport is sufficiently adapted to the needs of the economy as road transport. It highlights quite explicitly, however, that "in longer distances, options for road decarbonisation are more limited, and freight multimodality has to become economically attractive for shippers. Efficient co-modality is needed" [17] (p. 7).

It cannot be forgotten, however, that despite its potential environmental advantages, intermodal freight transport is more complex than unimodal road transport, since different actors are responsible for organizing and controlling different parts of the transport chain [23,25]. The involvement of various parties requires coordination, and operators must overcome any mistrust they may have, and understand the importance of integration within the transport chain [32-35]. Cooperation therefore needs to be encouraged among the different actors so users can find the logistic solutions that meet their needs and are economically competitive, as well as being more sustainable. Such collaboration should lead to better performance [35], including environmental performance, which should in turn lead to a greater share of the market.

\section{Motorways of the Sea in the Context of Intermodal Transport: Environmental Considerations}

In an attempt to stimulate intermodal transportation, MoS are now regarded as the maritime dimension of the core network of European corridors [17] (p. 14). The European Commission introduced the concept of MoS in the 2001 Transport Policy White Paper as a policy instrument to rebalance usage of transport modes and focus on intermodal transport development. The European Commission indicates that MoS constitute a special mode within SSS and can be defined as "existing or new sea-based transport services that are integrated in door-to-door logistical chains and concentrate flows of freight on viable, regular, frequent, high-quality and reliable Short Sea Shipping links. The deployment of the Motorways of the Sea network should absorb a significant part of the expected increase in road freight traffic, improve the accessibility of peripheral and island regions and states and reduce road congestion" [36]. MoS are thus conceived as high quality transport services based on SSS that offer a real competitive alternative to land transport and the EC strongly supports their further development and integration into the Trans-European Network (TEN-T). MoS can therefore be considered as a more limited concept than SSS, able to generate additional value [37]. Their development will depend on their capacity to offer efficient door-to-door transport that, in general terms, will show levels of competitiveness that can match those of the unimodal land transport chains [38-40]. Specifically, the EC's 2001 Transport Policy White Paper stated that MoS should offer efficient, regular, reliable, and frequent services that can compete in terms of transit time and price; and should have ports connected to the motorways and with effective hinterland connections, rapid administrative procedures and a high level of service. In the TEN-T guidelines, four main corridors for 
developing MoS projects are considered [41]: (1) Motorways of the Baltic Sea, connecting the Baltic countries to central and western European countries; (2) Motorway of the sea of western Europe, from Portugal and Spain via the Atlantic arc to the North Sea and the Irish Sea; (3) Motorways of the sea of southeast Europe (eastern Mediterranean), connecting the Adriatic to the Ionian Sea and the eastern Mediterranean, including Cyprus; (4) Motorways of the sea of southwest Europe (western Mediterranean), connecting Spain, France, Italy, Malta and linking southeast Europe to the Black Sea.

However, as European Coordinator for Motorways of the Sea Valente de Oliveira [40] suggests, the concept of MoS suffers from a lack of clarity among the players in the sector. In an attempt to overcome this deficiency, Gesé and Baird [42] (p. 402) point out that although MoS comprise part of an intermodal transport chain, it is the sea leg that primarily constitutes the MoS, which they define as "the mobile ship structure itself, which creates an MoS transport platform between two or more ports, and which, when combined with the port interchanges and intermodal land connections, offers essential quality features for users that are comparable with an alternative land motorway". Thus, the definition of MoS combines two elements: the infrastructure and the service provided. Based on the views expressed by players in the sector, Valente de Oliveira [40] highlights the main success factors associated with MoS. The most important of these is reliability, followed by the frequency of the line. One sailing a week is considered to be the minimum frequency, but it would go too far to decree at EU level that frequency should be at least three to five times a week. Other important factors are ease of access and use for clients, close contacts with potential clients and continuous exploration of the market, marketing of the concept among transport companies, and encouraging them to change their business operations and their traditional investment patterns. Essentially, as Beskovnik [43] (p. 30) points out, MoS "must be seen as a new transport concept in the wider context of the marketing of a multimodal logistics offer".

Greater use of this mode of transport should lead to a reduction in the problems traditionally associated with road transport, that is, lower energy consumption and, parallel to this, lower pollutant emissions, in addition to reduced road congestion and increased levels of safety. Hence, according to Valente de Oliveira [38], the European Union's 2020 target to reduce both GHG emissions and energy consumption by $20 \%$ reinforces the role of $\mathrm{MoS}$ in European transport policy. Since sea transport is theoretically more sustainable than transport by road, SSS and MoS offer feasible solutions for reducing the environmental problems associated with freight transport $[16,29,44]$.

Despite their advantages, there are many hurdles to successfully integrating SSS and MoS into multimodal logistical chains $[32,33,43,45]$. The main weaknesses found in these studies are the absence of an efficient image in door-to-door service-road transport of goods appears to offer a significant degree of flexibility that offsets the higher cost of door-to-door road transport, greater administrative complexity, and problems deriving from ports' efficiency, connections with their hinterland and the lack of flexibility of port services. More specifically, recent studies into MoS have emphasized four major barriers to their implementation [46,47]: (1) Regulatory (lack of uniformity among ports in the methods, standards and effectiveness of inspection measures they adopt; duplication in ship and cargo reporting procedures; barriers to port expansion plans, faced with opposition from residents and environmentalists; international road haulers' exploitation of the lack of harmonization in fuel prices and drivers' wages among states); (2) Technical (mainly associated with the incompatibility of loading units); (3) Commercial (low availability of new and fast Ro-Ro ships 
(Roll-on/roll-off) - the main type of ship used for MoS services - in the market for new services; the high average age of Ro-Ro ships in the spot market; commercial risk and high investment costs of Ro-Ro ships; lack of harmonization of conventions across transport modes; imbalanced freight flows in trading corridors; diversity in port charges from one port to another); (4) Environmental (high dependence on weather and climate conditions; poor image of "green" shipping for large parts of the maritime transport industry, especially regarding sulfur oxide ( $\mathrm{SOx}$ ) emissions).

Given these barriers, political initiatives to promote $\mathrm{MoS}$ are essential, and the European Commission must play a significant role in developing them. At the regulatory level, steps can be taken to remedy the harmonization problems outlined above, while reducing administrative barriers and simplifying custom formalities. Additionally, economic measures can be put in place, such as fixing charges for external costs related to congestion, air pollution, climate change, accidents and noise, which should theoretically lead to a reduction in the market share of road transport, or providing direct financial support for the development of MoS port infrastructure, or funds for the start-up phase of MoS projects. Regarding this last option, the EU Marco Polo programs offer subsidies for projects establishing new services designed to transfer cargo from road to more environmentally friendly transport modes such as rail and water. In a similar line, the Italian program Ecobonus offers economic incentives for road haulers that use SSS services, thus helping to promote the modal shift. This program offers discounts of between $20 \%$ and $30 \%$ on SSS service freight rates. In this way maritime transport is subsidized by an amount equivalent to the external costs avoided by not using the road option. In the Spanish case, which is what concerns us in this study, an agreement between France and Spain provided for a tender process to introduce an MoS service in the Atlantic area. As a result of this process, the Gijón-Sanint Nazaire MoS came into operation in 2010. France and Spain each contributed 15 million euros and the EU provided just over four million euros under the Marco Polo project. A more detailed discussion of Ecobonus and MoS policy in Spain and France can be found in Gese and Baird [48]. In any case, the significant problems of road congestion and the EU's goal to achieve a $20 \%$ reduction of greenhouse gas emissions by 2020 make MoS development a desirable goal that requires support.

In spite of the above, research into SSS or MoS to analyze the determinants of modal choice do not take environmental aspects into account as a parameter that could affect the decisions made [11,12,49-53] (see Table 1). Most authors have used the following variables: price, transit time, reliability and frequency. In addition, the level of importance ascribed to these variables differs in the studies shown in the table. For example, in the studies by Bergantino and Bolis [11,49], the most important attributes in modal choice are reliability and frequency; Pérez-Mesa et al. [52] consider cost and transit time as the most important variables, whereas Puckett et al. [53] prioritize cost and frequency. Likewise, environmental aspects are usually disregarded in studies analyzing the competitiveness of road and sea transport on different routes. There are a few exceptions, however, such as the study by Mange [54], which highlights the sustainability of MoS within a context of high traffic congestion, such as the Pyrenees or the Alps. But it also stresses the need for careful evaluation of their environmental impact, because if ships are not loaded to their full capacity, then the emissions they produce could be higher than those resulting from moving the freight by road. This is because the ships' engines do not meet the technical requirements - in terms of energy efficiency - if compared to the engines of modern road transport vehicles. Hjelle [18] puts forward similar arguments, stating that 
recent regulations on emissions reduction and environmental impact applied to the shipping industry have not been as strict as those affecting the European truck manufacturing industry. This argument is also made by the Court of Auditors in a recent report that criticized the effectiveness of Marco Polo programs in shifting traffic off the road [55]. Baindur and Viegas [46,47] also note that shipping is an important source of air pollutants, highlighting that sulfur oxide emissions from shipping are higher than from road transport. Vanherle and Leuven [19] compare the emissions and external costs involved in road haulage and SSS, concluding that there is no clear winner: SSS scores better than road haulage in terms of $\mathrm{CO}_{2}$ emissions (this pollutant has an impact on climate change) but scores less in terms of $\mathrm{NOx}, \mathrm{SO}_{2}$ and $\mathrm{PM}$ emission (pollutants that have an impact on regional air quality, thus affecting human health and the environment).

Table 1. Previous research on modal choice considering short sea shipping and motorways of the sea.

\begin{tabular}{ccccc}
\hline Paper; year & Modes & Region & Decision maker & $\begin{array}{c}\text { Transport attributes } \\
\text { considered }\end{array}$ \\
\hline $\begin{array}{c}\text { Puckett } \text { et al. [53]; } \\
\text { 2011 }\end{array}$ & Road vs. SSS & Canada-USA & Shippers & $\begin{array}{c}\text { Price, transit time, } \\
\text { frequency }\end{array}$ \\
\hline $\begin{array}{c}\text { Feo-Valero } \text { et al. } \\
\text { [12]; 2011 }\end{array}$ & Road vs. MoS & South-West Europe & Freight Forwarders & $\begin{array}{c}\text { Cost, transit time, } \\
\text { reliability, frequency }\end{array}$ \\
\hline $\begin{array}{c}\text { Pérez-Mesa } \text { et al. } \\
\text { [52]; 2010 }\end{array}$ & Road vs. MoS & $\begin{array}{c}\text { Southeast of Spain- } \\
\text { Southeast of France }\end{array}$ & $\begin{array}{c}\text { Shippers } \\
\text { (horticultural } \\
\text { operators) }\end{array}$ & $\begin{array}{c}\text { Cost, transit time, } \\
\text { transport quality, } \\
\text { frequency }\end{array}$ \\
\hline $\begin{array}{c}\text { García and } \\
\text { 2009 }\end{array}$ & Road $v$ s. SSS & Spain-Europe & $\begin{array}{c}\text { Shippers and } \\
\text { freight forwarders }\end{array}$ & $\begin{array}{c}\text { Cost, transit time } \\
\text { [50]; 2008 }\end{array}$ \\
$\begin{array}{c}\text { Brooks and Trifts } \\
\text { Road } v \text { s. SSS }\end{array}$ & Canada-USA & Shippers & $\begin{array}{c}\text { Price, transit time, } \\
\text { frequency }\end{array}$ \\
\hline $\begin{array}{c}\text { Bergantino and } \\
\text { Bolis [11]; 2008 }\end{array}$ & $\begin{array}{c}\text { Road } v s . \\
\text { Maritime Ro-Ro } \\
\text { service }\end{array}$ & Italy & Freight forwarders & $\begin{array}{c}\text { Price, transit time, } \\
\text { reliability, frequency }\end{array}$ \\
\hline $\begin{array}{c}\text { Bergantino and } \\
\text { Bolis [49]; 2004 }\end{array}$ & $\begin{array}{c}\text { Road } v s . \\
\text { Maritime Ro-Ro } \\
\text { service }\end{array}$ & Italy & Freight forwarders & $\begin{array}{c}\text { Price, transit time, } \\
\text { reliability, frequency }\end{array}$ \\
\hline
\end{tabular}

\section{The Decision Maker in Modal Choice}

Accepting the fact that intermodal transport contributes to achieving a more sustainable logistics, we consider it especially important to define the actor or actors ultimately responsible for making the decision about which modal solution to adopt. Part of the literature on intermodality is approached from the shippers' perspective, such as those requiring transport services (see, for example, [50,52,53]). Other works, however, explore the question from position of freight forwarders, logistics service providers or road haulers, that is to say, the organizations that offer transport services (see, for example, $[11,12,34,35,49,56])$. In general terms, and regardless of the perspective considered, both groups of studies aim to identify and evaluate the factors that ultimately determine the modal choice. 
Nevertheless, it is particularly relevant to determine who the decision maker really is, since this conditions the possible interventions or stimuli that might motivate the use of intermodal transportation.

Although it is true that in large companies, logistics and transportation issues - and hence choice between different transportation modes - are considered internally, Feo et al. [12] note that it is normal practice in smaller companies, which do not have their own logistics departments, to outsource transport services to external firms. These external companies will therefore make the decision on using intermodal solutions, provided they are more efficient alternatives that meet the client's specific requirements, particularly regarding delivery times. In some cases this might involve taking into account any resulting environmental benefits. Furthermore, outsourcing transport service not only affects small and medium-sized enterprises, by far the predominant model in Spain; large companies whose competitive advantage is not based on logistics activities often outsource this function to external logistics service providers, who will decide whether or not to use intermodal solutions.

Moreover, logistics service providers/road haulers are essentially responsible for coordinating intermodal transport chains involving semi-trailers, rather than containers. Woxenius and Bergqvist [57], following Schramm [58] note that the success of intermodal transport chains depends greatly on which agent acts as the coordinator and how well the operations are integrated. These authors highlight that whereas shipping companies, their agents or specialized sea forwarders take on the coordinating role in container transport, road transport firms or road-based forwarders predominate in the organization of transport chains involving semi-trailers. Moreover, Roll-on/Roll-off (Ro-Ro) operations are the main focus of MoS [59]. Focusing our research on MoS justifies, to a large degree, our approach from the perspective of the road transport firm.

The aforementioned arguments imply that logistics service providers/road haulers are the key decision makers in determining whether to use intermodal solutions in Ro-Ro SSS or MoS. Nevertheless, according to Gouvernal et al. [60] and López-Navarro et al. [56,61], these companies may be reluctant to use intermodal transport, since their business model is largely organized around road transport for which they have their own transportation networks. Using SSS and MoS entails significant adjustments and changes in the company, which may be a hindrance to the more widespread use of intermodal solutions [61]. Eng-Larsson and Kohn [10] put forward a similar argument in referring to rail intermodality, highlighting unwillingness on the part of logistics providers to invest in rail transport capacity, which comes into conflict with their own important road transport networks.

Intermodal transport, however, owes a good part of its success to the coordination among the participating operators, and in this sense shippers also play a role in its development. Perhaps this role is not especially important in the case of MoS, where quality standards can allow logistics service providers/road haulers to configure competitive intermodal chains that offer a real alternative to road transport. In any event, the supposedly greater sustainability of MoS would be an added value in the environmental strategy of shippers. Shippers do not want to be associated with pollution; rather, they want to portray an environmentally friendly image for their products. Although we do not know of any similar cases in MoS, we can cite the rail motorway initiative between Le Boulou (France) and Bettembourg (Luxembourg), run by the Lorry-Rail/Viia rail operator. This company offers logistics service providers/road haulers using its services a $\mathrm{CO}_{2}$-saving certificate accrediting the number of kilograms of $\mathrm{CO}_{2}$ that have not been emitted, which is calculated according to the number of semi-trailers the company has transported on the rail motorway. A similar certificate is also issued to shippers. 
In this case, the rail service operator certifies that the shipper, through the corresponding logistics services provider, has reduced the amount of $\mathrm{CO}_{2}$ emitted by so many kilos as a result of using the rail motorway. This is a clear incentive for shippers to encourage their logistics service suppliers to use this intermodal service.

However, the shipper's role is more relevant in the case of Ro-Ro SSS lines that do not comply with the standards of quality in terms of frequency or transit times attributed to MoS. These lines have greater restrictions that hinder their regular use by logistics service providers/road haulers, since they often make it impossible to fulfill the conditions their clients demand regarding service quality. As a result, shippers' operations may have to be modified, for example by obliging them to adjust their inventories, or more planning and coordination between the two parties may be needed to adapt to a lower number of departures. Thus, as Eng-Larsson and Kohn [10] state, choice of mode may not depend only on the transport operator, but can also require the shipper's involvement. In any case, either directly or indirectly, the shipper also plays a key role in extending the use of intermodal chains; on this question, the environmental benefits can be decisive, depending on just how proactive the shipper's strategy is in this field.

\section{Decision Makers' Bases for Comparing Environmental Impacts among Transport Modes}

Regardless of who makes the decisions concerning modal shift-logistics service providers/road haulers, freight forwarders or shippers - the question remains of how decision makers can compare the environmental impacts between transport modes. Aspects such as price, frequency or transit times are easy to determine, but this is not the case with environmental or other external costs. There seems to be a common assumption that the environmental impacts deriving from sea transport are lower than those from road transport. As noted above, however, recent research has challenged this assumption and called for more thorough analyses. A recent report by the European Court of Auditors questions the effectiveness of the European Marco Polo programs in achieving their goals of redirecting road traffic toward other more sustainable modes, and points out that "although it is generally acknowledged that alternatives to road-only transport usually provide greater benefits for the broader community, the real leverage level is likely to be much lower. This is because of the fact that, between 2004 and 2010, the Marco Polo calculator dataused were outdated and therefore inaccurate. Since 2004, road transport has gradually become cleaner as a result of research and innovation. This was not taken into account by the Commission for its calls from 2005 to 2010. It was only in the 2011 call that new coefficients and a new methodology were used when quantifying the impact of freight transport by rail, inland waterways and short sea shipping" [55] (p. 18). A comparison of the Marco Polo calculator coefficients over time is shown in Table 2.

As Gesé and Baird [42] noted, there is no general agreement on how to quantify external cost for each transport mode. In this study, we will use the external cost calculator for Marco Polo freight transport project proposals (call 2013) to compare the environmental costs of road haulage and MoS. This tool is used by the EC for subsidizing projects aiming to shift the volume of freight transportation by road to more environmentally friendly transport modes. Furthermore, and given the geographic scope of our study, we will also refer to the transport chain simulator used by the Spanish association for the promotion of SSS - the Shortsea Promotion Centre SPAIN [62]. This calculation tool is 
available on the Shortsea Promotion Centre website; members of this association include port authorities, shipping companies and the main Spanish road hauler association. The transport chain simulator compares road transport between two points and their intermodal alternative using SSS and shows the following outputs: cost (in euros), time (in hours), distance (in kms), external costs (in euros) and emissions (in $\mathrm{kg}$ of $\mathrm{CO}_{2}$ ).

Table 2. Comparison of the Marco Polo Calculator Coefficients over time (euro per ton-kilometer) ${ }^{\text {a }}$.

\begin{tabular}{|c|c|c|c|c|c|c|}
\hline Transport mode & Subtypes & 2003 call & 2004 call & 2011 call & \multicolumn{2}{|c|}{2013 call } \\
\hline Road & & 0.024 & 0.035 & 0.018 & \multicolumn{2}{|c|}{0.0185} \\
\hline \multirow{2}{*}{ Rail } & Diesel & \multirow{2}{*}{0.012} & \multirow{2}{*}{0.015} & 0.015 & \multicolumn{2}{|c|}{0.0147} \\
\hline & Electric & & & 0.004 & \multicolumn{2}{|c|}{0.0044} \\
\hline & & & & \multirow{2}{*}{$\begin{array}{c}\text { Conventional } \\
\text { fuel }\end{array}$} & \multicolumn{2}{|c|}{ Conventional fuel } \\
\hline & & & & & $\begin{array}{c}\text { Low } \\
\text { sulfur fuel }\end{array}$ & $\begin{array}{l}\text { High sulfur } \\
\text { fuel }\end{array}$ \\
\hline \multirow{6}{*}{$\begin{array}{l}\text { Short sea } \\
\text { shipping }\end{array}$} & General/bulk & \multirow{6}{*}{0.004} & \multirow{6}{*}{0.009} & 0.007 & 0.0047 & 0.0072 \\
\hline & Container ship & & & 0.005 & 0.0035 & 0.0052 \\
\hline & $\begin{array}{l}\text { Ro-Ro/Ro-Pax } \\
\quad(<17 \mathrm{kn})\end{array}$ & & & 0.005 & 0.0045 & 0.0054 \\
\hline & $\begin{array}{l}\text { Ro-Ro/Ro-Pax } \\
(17-20 \mathrm{kn})\end{array}$ & & & 0.009 & 0.0076 & 0.0088 \\
\hline & $\begin{array}{c}\text { Ro-Ro/Ro-Pax } \\
\quad(20-23 \mathrm{kn})\end{array}$ & & & 0.013 & 0.0114 & 0.0133 \\
\hline & $\begin{array}{c}\text { Ro-Ro/Ro-Pax } \\
\quad(>23 \mathrm{kn})\end{array}$ & & & 0.020 & 0.0165 & 0.0196 \\
\hline
\end{tabular}

\footnotetext{
${ }^{\mathrm{a}}$ In road and rail transport the Marco Polo calculator coefficients consider environmental externalities (air pollution, climate change and noise) and socio-economic externalities (accidents and congestion); in SSS, only environmental externalities (air pollution and climate change) are considered. Source: European Court of Auditors [55] and Brons and Christidis [63].
}

The first rows of Table 3 show the coefficients used by both tools to compare the two transport modes. However, the coefficients the tools use, and the outputs provided, are not altogether comparable. The Shortsea Promotion Centre Spain simulator calculates $\mathrm{CO}_{2}$ emissions in kilograms; external costs are shown in Euros per shipment, although they can be recalculated as euros per ton-kilometer. However, there is no indication as to the methodologies used to calculate the values or to what exactly is included in the external costs. The Marco Polo calculator expresses values in euros per ton-kilometer; for road transport, it also distinguishes between environmental externalities (air pollution, climate change and noise) and socio-economic externalities (accidents and congestion), whereas only environmental externalities (air pollution and climate change) are considered for SSS. The Marco Polo calculator follows the methodology set out in the handbook on estimation of external costs in the transport sector, IMPACT [64]. Specifically, with regard to air pollution the calculations for road, rail and inland waterways are based on the IMPACT study, the TREMOVE [65] model, the HEATCO [66] study and the CAFE [67] project; for SSS, emissions estimates from the EX-TREMIS [68] database are used in combination with cost factors from HEATCO and CAFE. Regarding climate change, the 
calculations for road, rail and inland waterways are based on the approach of IMPACT study and TREMOVE model; for SSS, the EX-TREMIS database and the IMPACT study are used.

In the case of the Shortsea Promotion Centre Spain simulator, the value of the coefficients strongly favor the intermodal option (a differential of $71.35 \%$ in the case of external costs and $88.77 \%$ in the case of $\mathrm{CO}_{2}$ emissions); this option is therefore clearly preferable if decision makers use this tool to calculate the environmental/external impacts of their transportation activity. As shown in Table 2, the Marco Polo calculator considers three subcategories of SSS, based on ship/cargo type: general cargo/bulk, container and Ro-Ro/Ro-Pax. Moreover, for Ro-Ro/Ro-Pax ships, cost coefficients are calculated for different speed categories ( $<17 \mathrm{kn}, 17-20 \mathrm{kn}, 20-23 \mathrm{kn}$ and $>23 \mathrm{kn}$ ). In addition to conventional fuel-differentiating between low sulfur and high sulfur fuel-other alternative fuel technologies are also considered (LNG, methanol, seawater scrubbing and freshwater scrubbing). The maritime option (in euros per ton-kilometer) only offers a less satisfactory environmental performance than road transport in the case of Ro-Ro/Ro-Pax ships with speeds above $23 \mathrm{k}$. In the case of the MoS operating in Spain, these conditions are met in three of the eight lines considered (Bilbao-Portsmouth, Santander-Portsmouth and Barcelona-Civitavecchia), all of them operated by Ro-Pax ships. As Gesé and Baird [42] note, exclusively Ro-Pax services generate greater emissions due to their higher speeds.

Note that the environmental cost differentials for the two modes of transport in the Marco Polo calculator are somewhat lower than those of the Shortsea Promotion Centre simulator. Although the coefficients of the Marco Polo calculator can be considered more reliable, since they are based on a more comprehensive methodology, the Shortsea Promotion Centre simulator may be more popular among users owing to its ease of use and the results it offers, which include costs, transit times and environmental impacts. There is clearly a need to develop comprehensive, user-friendly tools that decision makers can adapt to the features of a range of options, while at the same time thoroughly addressing the parameters we consider in this study.

\section{Comparing the Environmental Costs of Road and MoS in the Spanish Case}

It is insufficient, however, to simply compare the values reported in Table 3 to evaluate the extent of environmental impact of MoS vis-à-vis road, particularly because the distances can vary depending on the route taken. We therefore made a comparative analysis, based on the Marco Polo calculator's coefficients (call 2013), of road use and the intermodal option with MoS for a series of different routes. This methodology is considered adequate for comparative purposes and has been applied in other studies $[42,69]$. The routes considered correspond to Spain's three main transport corridors (Mediterranean, central and Atlantic), and for each one of these we considered three departure cities: Zaragoza, Madrid and Seville for the central corridor; Barcelona, Valencia and Almeria for the Mediterranean corridor; and A Coruña, Oviedo and Vitoria for the Atlantic corridor (Figure 1). Consistent with the MoS analyzed in this study, several relevant destination cities were selected: London in the case of the Santander-Portsmouth and Bilbao-Portsmouth MoS; Paris for the Gijón-Saint Nazaire MoS; Brussels for the Bilbao-Zeebrugge MoS; Milan for the Barcelona-Genoa MoS; Rome for the Barcelona-Civitavecchia MoS; Florence for the Barcelona-Savona-Livorno MoS and, finally, Salerno for the Valencia-Salerno MoS. For each of these routes (nine for each MoS) we 
compared the environmental costs of the two transport modes: "road only," and "intermodal with MoS." The results are reported in Table 4.

The analysis of the results in Table 4 reveals differences between the MoS of the Atlantic and Mediterranean arcs. In the Atlantic case, the values for environmental costs on routes to London are, in general, unfavorable for the intermodal option. This is the case on all the routes where the Bilbao-Portsmouth line is used, and on seven of the nine routes that use the Santander-Portsmouth line. As Gesé and Baird [42] note, because passenger transport is prioritized on these two lines, transit times are kept to $24 \mathrm{~h}$ or less so passengers spend no more than one night on the ship. For this reason, speeds above $23 \mathrm{kn}$ are required, which increases fuel consumption and environmental costs. The use of high-speed vessels in SSS may have positive effects in logistics performance and effectiveness in terms of transport time; however, because of its high fuel usage, it also implies negative environmental effects. In the case of routes to Paris, environmental costs are lower in five of the nine routes considered when the intermodal option with the Gijón-Saint Nazaire line is used. The "road only" option is preferable on four of the routes; specifically and for each of the three transport corridors considered, road is preferable for freight departure points that are closer to the Pyrenees (Zaragoza as opposed to Madrid and Seville; Barcelona and Valencia as opposed to Almeria; Vitoria, as opposed to Oviedo and A Coruna), where the distance to the destination-Paris - by road is shorter and farther from the port of loading-Gijón. Although this line is also covered by a Ro-Pax ship, the shorter sailing distance (practically half that of the aforementioned lines) means that the transit time is less than $24 \mathrm{~h}$ even though the speed is notably slower. Finally, in the case of routes to Brussels (considering the use of the Bilbao-Zeebrugge MoS) only one "road only" route has lower environmental costs, that departing from Barcelona, due to the shorter distance by road to the destination.

On routes between Spain and Italy (considering the use of the Mediterranean MoS), the geographical features of the two countries mean that the maritime option significantly reduces the kilometers to be covered in most of the routes analyzed. On routes to Milan, Florence and Salerno, the intermodal option (using the Barcelona-Genoa, Barcelona-Savona-Livorno and Valencia-Salerno MoS, respectively) is preferable in all cases with regard to environmental costs. On routes to Rome, in only three cases - those departing from cities in the Atlantic corridor--the road haulage option is more favorable than the intermodal option (via the Barcelona-Civitavecchia MoS), although the values are very similar. On this MoS in particular, the advantage in terms of transit time compared to the road is significant and, in this sense, the ship could even travel at a considerably slower speed while still maintaining this advantage, thus reducing fuel consumption and environmental costs. Although in this case freight transport is also important (capacity for trucks is significantly higher than on the lines from Santander and Bilbao to Portsmouth), the reason why higher cruising speeds are used is probably because of the passenger transport between two tourist destinations-Barcelona and Rome - as in the aforementioned MoS between Spain and England, and the need to offer limited transit times. 
Table 3. Comparative analysis of cost coefficients for road transport and SSS - the case of Spanish motorways of the case.

\begin{tabular}{|c|c|c|c|c|c|c|c|c|c|c|c|c|c|c|}
\hline & \multicolumn{2}{|c|}{$\begin{array}{c}\text { Shortsea Promotion Centre } \\
\text { Spain simulator } \\
\end{array}$} & \multicolumn{12}{|c|}{ Marco Polo Calculator (environmental cost (EnvCt) and external cost (ExtCt) coefficients—euro per ton-kilometer) } \\
\hline & \multirow{2}{*}{$\begin{array}{c}\text { External costs } \\
\text { (euros per } \\
\text { ton-kilometer) }\end{array}$} & \multirow{2}{*}{$\begin{array}{c}\mathrm{CO}_{2} \text { emissions } \\
\text { (kg per } \\
\text { ton-kilometer) } \\
\end{array}$} & \multicolumn{2}{|c|}{$\begin{array}{c}\text { Low sulfur fuel } \\
(17-20 \mathrm{kn}) \\
\end{array}$} & \multicolumn{2}{|c|}{$\begin{array}{c}\text { Low sulfur fuel } \\
(20-23 \mathrm{kn}) \\
\end{array}$} & \multicolumn{2}{|c|}{$\begin{array}{c}\text { Low sulfur fuel } \\
(>\mathbf{2 3} \mathbf{~ k n}) \\
\end{array}$} & \multicolumn{2}{|c|}{$\begin{array}{l}\text { High sulfur fuel } \\
\quad(17-20 \text { kn) } \\
\end{array}$} & \multicolumn{2}{|c|}{$\begin{array}{c}\text { High sulfur fuel } \\
(20-23 \mathrm{kn}) \\
\end{array}$} & \multicolumn{2}{|c|}{$\begin{array}{l}\text { High sulfur fuel } \\
\quad(>23 \mathbf{~ k n}) \\
\end{array}$} \\
\hline & & & EnvCt & ExtCt & EnvCt & ExtCt & EnvCt & ExtCt & EnvCt & ExtCt & EnvCt & ExtCt & EnvCt & ExtCt \\
\hline Road & 0.0185 & 0.1229 & 0.01443 & 0.0185 & 0.01443 & 0.0185 & 0.01443 & 0.0185 & 0.01443 & 0.0185 & 0.01443 & 0.0185 & 0.01443 & 0.0185 \\
\hline Short sea shipping & 0.0053 & 0.0138 & 0.00763 & 0.00763 & 0.01147 & 0.01147 & 0.0165 & 0.0165 & 0.00885 & 0.00885 & 0.01332 & 0.01332 & 0.01963 & 0.01963 \\
\hline Differential -in relation to road (\%)- & $71.35 \%$ & $88.77 \%$ & $47.12 \%$ & $58.75 \%$ & $20.51 \%$ & $38.0 \%$ & $-14.34 \%$ & $10.81 \%$ & $38.67 \%$ & $52.16 \%$ & $7.69 \%$ & $28.0 \%$ & $-36.03 \%$ & $-6.10 \%$ \\
\hline \multicolumn{15}{|c|}{ Barcelona-Genoa (2 departures/week) } \\
\hline \multicolumn{15}{|c|}{ Distance: 352 nm; 19.50 h (18 h sailing); Service speed: 19.6 kn } \\
\hline \multicolumn{15}{|c|}{ Vessel: Excellent/Fantastic (Ro-Pax); Maximum speed: 24 and 23 kn; Fuel: IFO 380} \\
\hline \multicolumn{15}{|c|}{ Barcelona-Civitavecchia (6 departures/week) } \\
\hline \multicolumn{15}{|c|}{ Distance: 439 nm; 20 h (18.5 h sailing); Service speed: 23.73 kn } \\
\hline \multicolumn{15}{|c|}{ Vessel: Cruise Barcelona-Cruise Roma (Ro-Pax); Maximum speed: 27.5 kn; } \\
\hline \multicolumn{15}{|l|}{ Fuel: IFO 380} \\
\hline \multicolumn{15}{|c|}{ Valencia/Barcelona-Savona/Livorno ${ }^{(a)}$ (3 departures/week) } \\
\hline \multicolumn{15}{|c|}{ Distance (Barcelona-Savona): 335 nm; 20 h (18.5 h sailing); Service speed: 18.1 kn } \\
\hline \multicolumn{15}{|c|}{ Vessel: Two vessels Eurocargo model (Ro-Ro); Maximum speed: 22 kn; } \\
\hline \multicolumn{15}{|l|}{ Fuel: IFO 380} \\
\hline \multicolumn{15}{|c|}{ Valencia-Cagliari-Salerno $^{(a)}$ (3 departures/week) } \\
\hline \multicolumn{15}{|c|}{ Distance (Valencia-Cagliari): 455 nm; 26 h (24.5 h sailing); Service speed: 18.6 kn } \\
\hline \multicolumn{15}{|c|}{ Vessel: Two vessels Eurocargo model (Ro-Ro); Maximum speed: 22 kn; } \\
\hline Fuel: IFO 380 & & & & & & & & & & & & & & \\
\hline
\end{tabular}


Table 3. Cont

\begin{tabular}{|c|c|c|c|c|c|c|c|c|c|c|c|c|c|c|}
\hline & \multicolumn{2}{|c|}{$\begin{array}{c}\text { Shortsea Promotion Centre } \\
\text { Spain simulator }\end{array}$} & \multicolumn{12}{|c|}{ Marco Polo Calculator (environmental cost (EnvCt) and external cost (ExtCt) coefficients—euro per ton-kilometer) } \\
\hline & \multirow{2}{*}{$\begin{array}{c}\text { External costs } \\
\text { (euros per } \\
\text { ton-kilometer) }\end{array}$} & \multirow{2}{*}{$\begin{array}{c}\mathrm{CO}_{2} \text { emissions } \\
\text { (kg per } \\
\text { ton-kilometer) }\end{array}$} & \multicolumn{2}{|c|}{$\begin{array}{c}\text { Low sulfur fuel } \\
\quad(17-20 \mathrm{kn}) \\
\end{array}$} & \multicolumn{2}{|c|}{$\begin{array}{c}\text { Low sulfur fuel } \\
(20-23 \mathrm{kn}) \\
\end{array}$} & \multicolumn{2}{|c|}{$\begin{array}{c}\text { Low sulfur fuel } \\
\text { (>23 kn) }\end{array}$} & \multicolumn{2}{|c|}{$\begin{array}{l}\text { High sulfur fuel } \\
\quad(17-20 \mathrm{kn}) \\
\end{array}$} & \multicolumn{2}{|c|}{$\begin{array}{l}\text { High sulfur fuel } \\
\quad(20-23 \text { kn) } \\
\end{array}$} & \multicolumn{2}{|c|}{$\begin{array}{l}\text { High sulfur fuel } \\
\qquad(>23 \mathbf{~ k n})\end{array}$} \\
\hline & & & EnvCt & ExtCt & EnvCt & ExtCt & EnvCt & ExtCt & EnvCt & ExtCt & EnvCt & ExtCt & EnvCt & ExtCt \\
\hline Road & 0.0185 & 0.1229 & 0.01443 & 0.0185 & 0.01443 & 0.0185 & 0.01443 & 0.0185 & 0.01443 & 0.0185 & 0.01443 & 0.0185 & 0.01443 & 0.0185 \\
\hline Short sea shipping & 0.0053 & 0.0138 & 0.00763 & 0.00763 & 0.01147 & 0.01147 & 0.0165 & 0.0165 & 0.00885 & 0.00885 & 0.01332 & 0.01332 & 0.01963 & 0.01963 \\
\hline Differential - in relation to road (\%)- & $71.35 \%$ & $88.77 \%$ & $47.12 \%$ & $58.75 \%$ & $20.51 \%$ & $38.0 \%$ & $-14.34 \%$ & $10.81 \%$ & $38.67 \%$ & $52.16 \%$ & $7.69 \%$ & $28.0 \%$ & $-36.03 \%$ & $-6.10 \%$ \\
\hline \multicolumn{15}{|c|}{ Gijón-Saint Nazaire (3 departures/week) } \\
\hline \multicolumn{15}{|c|}{ Distance: $274 \mathrm{~nm} ; 16 \mathrm{~h}$ (14.5 h sailing); Service speed: $18.9 \mathrm{kn}$} \\
\hline \multicolumn{15}{|c|}{ Vessel: Scintu (Ro-Pax); Maximum speed: 24 kn; Fuel: IFO 380} \\
\hline Bilbao-Zeebl & ge ( 2 departures $/ w e$ & & & & & & & & & & & & & \\
\hline
\end{tabular}

Distance: $705 \mathrm{~nm} ; 39 \mathrm{~h}$ (37.5 h sailing); Service speed. $18.8 \mathrm{kn}$

Vessel: Stena Freighter/Stena Ark Forwarder (Ro-Ro); Maximum speed: 22 kn;

Fuel: IFO 380

Santander-Portsmouth (2 departures/week)

Distance: 532 nm; 24 h (22.5 h sailing); Service speed: 23.6 kn

Vessel: Port Aven/Cap Finisterre (Ro/Pax); Maximum speed: 27 kn; Fuel: IFO 380

Bilbao-Portsmouth (2 departures/week)

Distance: $555 \mathrm{~nm}$; 24 h (22.5 h sailing); Service speed: $24.7 \mathrm{kn}$

Vessel: Cap Finisterre (Ro-Pax); Maximum speed: 27 kn; Fuel: IFO 380

Data on the number of departures, vessels used, transit time, maximum speed of ships, and fuel used were obtained from the shipping companies' websites. When this information was not available, it was requested from shipping companies by telephone. The information shown was obtained in November 2013. The transit time was reduced by $1.5 \mathrm{~h}$ in each case assuming a duration of $45 \mathrm{~min}$ in the departure and access operations in each port. Data on the distance in nautical miles between ports were obtained from a specific online calculator [70]. ${ }^{(a)}$ The service speed was calculated from a reference to one part of the journey. Cells in black indicate the coefficients applicable to each line according to the service speed used. 
Figure 1. Origin of the routes analyzed and Spanish ports linked by MoS.

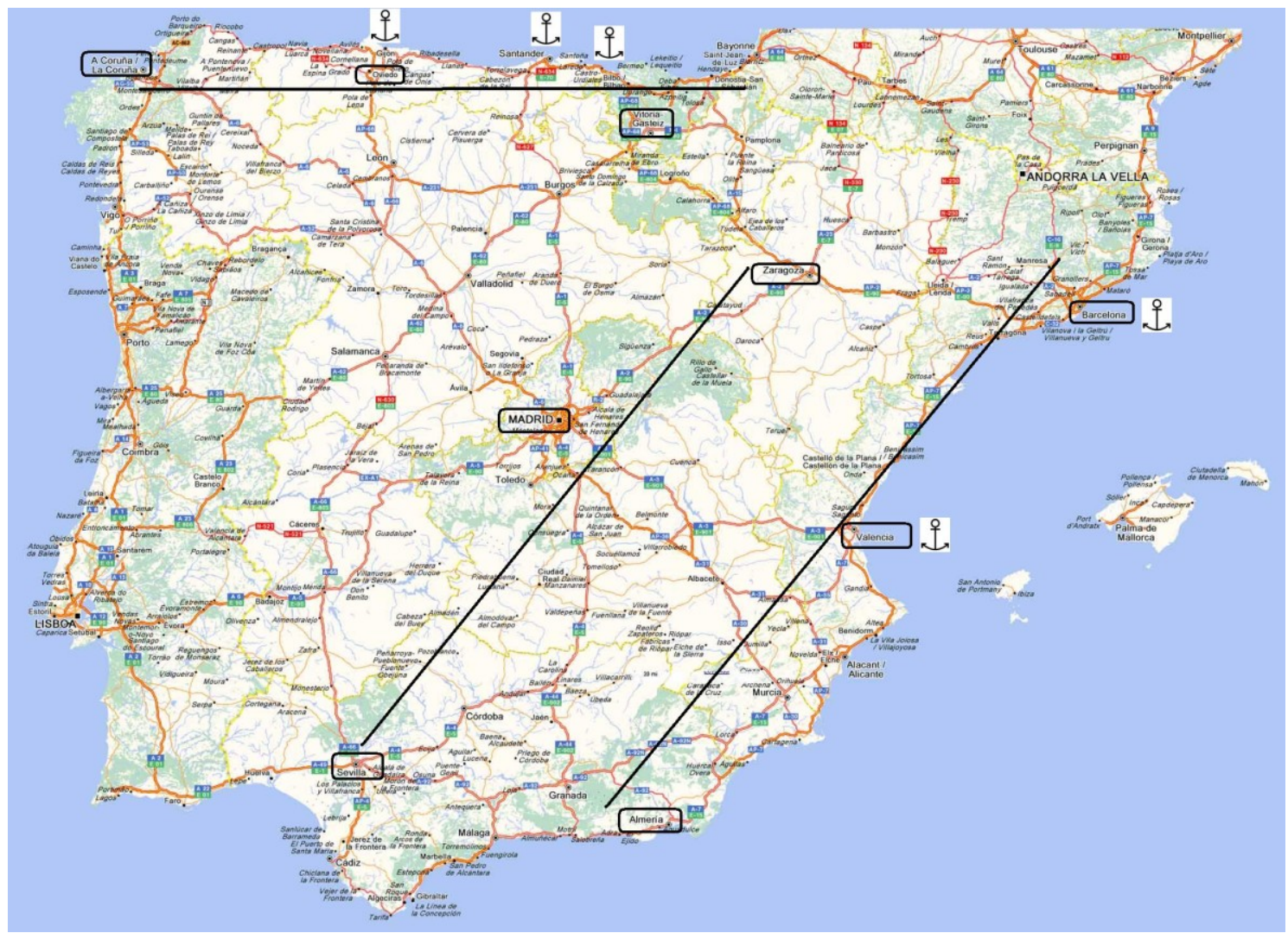

\section{Discussion and Conclusions}

Increases in transportation are interpreted as positive indicators of economic growth. There are also some negative elements associated with growing volumes of transported freight however, especially in terms of increased pollutant emissions and their contribution to global warming, but also other external costs such as noise, traffic congestion and accidents - this last factor particularly relevant in the case of road transport. Within the European Union, it has been clearly stated that the current transport system is not viable and several policies have been implemented in an attempt to achieve a more efficient and, above all, more sustainable transport system. One of these policies aims at encouraging intermodal transport, by granting MoS a more significant role as the maritime dimension of the core network of European corridors.

Despite the important environmental impacts deriving from freight transport, to date little importance has been attached to this dimension in the modal choice literature. More specifically, and strictly within the field covered by the present study - namely SSS and MoS - the environmental factor has not been included in studies on modal choice. This is somewhat surprising given the fact that environmental arguments are usually presented as decisive in justifying intermodal solutions. Consequently, the results of the literature review conducted in our research on modal choice in the field of SSS and MoS justify the need for future research to include environmental aspects as a relevant attribute. 
Table 4. Comparison of the environmental costs (euro per ton) of road and MoS for different routes in the Spanish case ${ }^{(a)}$.

\begin{tabular}{|c|c|c|c|c|c|}
\hline Route & $\begin{array}{c}\mathbf{k m} \\
(\text { road })\end{array}$ & $\begin{array}{c}\text { Environmental } \\
\text { Costs } \\
\end{array}$ & $\begin{array}{c}\mathbf{k m} \\
(\mathrm{road})\end{array}$ & $\begin{array}{c}\text { km } \\
\text { (sea) }\end{array}$ & $\begin{array}{c}\text { Environmental } \\
\text { Costs } \\
\end{array}$ \\
\hline & \multicolumn{2}{|c|}{ Road only } & \multicolumn{3}{|c|}{$\begin{array}{c}\text { Intermodal } \\
\text { (MoS Bilbao-Portsmouth) }\end{array}$} \\
\hline Zaragoza-London & 1552 & 22.37 & 428 & 1027 & 26.34 \\
\hline Madrid-London & 1768 & 25.49 & 522 & 1027 & 27.69 \\
\hline Seville-London & 2238 & 32.27 & 982 & 1027 & 34.33 \\
\hline Barcelona-London & 1540 & 22.20 & 734 & 1027 & 30.75 \\
\hline Valencia-London & 1881 & 27.12 & 736 & 1027 & 30.78 \\
\hline Almería-London & 2330 & 33.60 & 1059 & 1027 & 35.44 \\
\hline Vitoria-London & 1416 & 20.41 & 189 & 1027 & 22.89 \\
\hline Oviedo-London & 1697 & 24.47 & 412 & 1027 & 26.11 \\
\hline \multirow[t]{2}{*}{ A Coruña-London } & 1961 & 28.28 & 677 & 1027 & 29.93 \\
\hline & \multicolumn{2}{|c|}{ Road only } & \multicolumn{3}{|c|}{$\begin{array}{c}\text { Intermodal } \\
\text { (MoS Santander-Portsmouth) }\end{array}$} \\
\hline Zaragoza-London & 1552 & 22.37 & 526 & 985 & 26.93 \\
\hline Madrid-London & 1768 & 25.49 & 549 & 985 & 27.26 \\
\hline Seville-London & 2238 & 32.27 & 948 & 985 & 33.02 \\
\hline Barcelona-London & 1540 & 22.20 & 831 & 985 & 31.33 \\
\hline Valencia-London & 1881 & 27.12 & 833 & 985 & 31.36 \\
\hline Almería-London & 2330 & 33.60 & 1086 & 985 & 35.01 \\
\hline Vitoria-London & 1416 & 20.41 & 286 & 985 & 23.46 \\
\hline Oviedo-London & 1697 & 24.47 & 317 & 985 & 23.91 \\
\hline A Coruña-London & 1961 & 28.28 & 581 & 985 & 27.72 \\
\hline
\end{tabular}

\begin{tabular}{|c|c|c|c|c|c|}
\hline Route & $\begin{array}{c}\text { km } \\
(\text { road })\end{array}$ & $\begin{array}{c}\text { Environmental } \\
\text { Costs }\end{array}$ & $\begin{array}{c}\mathbf{k m} \\
(\text { road })\end{array}$ & $\begin{array}{l}\text { km } \\
\text { (sea) }\end{array}$ & $\begin{array}{l}\text { Environmental } \\
\text { Costs }\end{array}$ \\
\hline & \multicolumn{2}{|c|}{ Road only } & \multicolumn{3}{|c|}{$\begin{array}{c}\text { Intermodal } \\
\text { (MoS Barcelona-Civitavecchia) }\end{array}$} \\
\hline Zaragoza-Rome & 1642 & 23.69 & 382 & 813 & 21.47 \\
\hline Madrid-Rome & 1953 & 28.18 & 693 & 813 & 25.96 \\
\hline Seville-Rome & 2345 & 33.84 & 1070 & 813 & 31.40 \\
\hline Barcelona-Rome & 1355 & 19.55 & 73 & 813 & 17.01 \\
\hline Valencia-Rome & 1695 & 24.46 & 422 & 813 & 22.05 \\
\hline Almería-Rome & 2144 & 30.94 & 869 & 813 & 28.50 \\
\hline Vitoria-Rome & 1693 & 24.43 & 604 & 813 & 24.67 \\
\hline Oviedo-Rome & 1973 & 28.47 & 966 & 813 & 29.90 \\
\hline \multirow[t]{2}{*}{ A Coruña-Rome } & 2238 & 32.29 & 1162 & 813 & 32.73 \\
\hline & \multicolumn{2}{|c|}{ Road only } & \multicolumn{3}{|c|}{$\begin{array}{c}\text { Intermodal } \\
\text { (MoS Barcelona-Genoa) }\end{array}$} \\
\hline Zaragoza-Milan & 1266 & 18.27 & 450 & 652 & 12.26 \\
\hline Madrid-Milan & 1578 & 22.77 & 761 & 652 & 16.75 \\
\hline Seville-Milan & 1970 & 28.43 & 1138 & 652 & 22.19 \\
\hline Barcelona-Milan & 980 & 14.14 & 141 & 652 & 7.80 \\
\hline Valencia-Milan & 1321 & 19.06 & 490 & 652 & 12.84 \\
\hline Almería-Milan & 1769 & 25.53 & 937 & 652 & 19.29 \\
\hline Vitoria-Milan & 1318 & 19.02 & 672 & 652 & 15.47 \\
\hline Oviedo-Milan & 1598 & 23.06 & 1034 & 652 & 20.69 \\
\hline A Coruña-Milan & 1863 & 26.88 & 1230 & 652 & 23.52 \\
\hline
\end{tabular}


Table 4. Cont.

\begin{tabular}{|c|c|c|c|c|c|}
\hline Route & $\begin{array}{c}\mathbf{k m} \\
(\mathrm{road})\end{array}$ & $\begin{array}{c}\text { Environmental } \\
\text { Costs } \\
\end{array}$ & $\begin{array}{c}\text { km } \\
\text { (road) }\end{array}$ & $\begin{array}{c}\mathbf{k m} \\
\text { (sea) }\end{array}$ & $\begin{array}{c}\text { Environmental } \\
\text { Costs } \\
\end{array}$ \\
\hline & \multicolumn{2}{|c|}{ Road only } & \multicolumn{3}{|c|}{$\begin{array}{c}\text { Intermodal } \\
\text { (MoS Gijón-Saint Nazaire) } \\
\end{array}$} \\
\hline Zaragoza-Paris & 1057 & 15.25 & 1013 & 507 & 19.10 \\
\hline Madrid-Paris & 1271 & 18.34 & 906 & 507 & 17.56 \\
\hline Seville-Paris & 1743 & 25.15 & 1233 & 507 & 22.28 \\
\hline Barcelona-Paris & 1037 & 14.96 & 1318 & 507 & 23.51 \\
\hline Valencia-Paris & 1378 & 19.88 & 1264 & 507 & 22.73 \\
\hline Almería-Paris & 1826 & 26.35 & 1450 & 507 & 25.41 \\
\hline Vitoria-Paris & 920 & 13.28 & 774 & 507 & 15.66 \\
\hline Oviedo-Paris & 1201 & 17.33 & 471 & 507 & 11.28 \\
\hline \multirow[t]{2}{*}{ A Coruña-Paris } & 1466 & 21.15 & 725 & 507 & 14.95 \\
\hline & \multicolumn{2}{|c|}{ Road only } & \multicolumn{3}{|c|}{ Intermodal (Bilbao-Zeeburgge) } \\
\hline Zaragoza-Brussels & 1359 & 19.61 & 418 & 1305 & 17.58 \\
\hline Madrid-Brussels & 1567 & 22.61 & 512 & 1305 & 18.94 \\
\hline Seville-Brussels & 2045 & 29.51 & 972 & 1305 & 25.58 \\
\hline $\begin{array}{c}\text { Barcelona- } \\
\text { Brussels } \\
\end{array}$ & 1339 & 19.32 & 724 & 1305 & 22.00 \\
\hline Valencia-Brussels & 1680 & 24.24 & 726 & 1305 & 22.03 \\
\hline Almería-Brussels & 2129 & 30.72 & 1049 & 1305 & 26.69 \\
\hline Vitoria-Brussels & 1223 & 17.65 & 179 & 1305 & 14.13 \\
\hline Oviedo-Brussels & 1503 & 21.69 & 402 & 1305 & 17.35 \\
\hline A Coruña-Brussels & 1768 & 25.51 & 667 & 1305 & 21.17 \\
\hline
\end{tabular}

\begin{tabular}{|c|c|c|c|c|c|}
\hline Route & $\begin{array}{c}\mathbf{k m} \\
(\mathrm{road})\end{array}$ & $\begin{array}{c}\text { Environmental } \\
\text { Costs } \\
\end{array}$ & $\begin{array}{c}\mathbf{k m} \\
(\text { road })\end{array}$ & $\begin{array}{c}\text { km } \\
\text { (sea) }\end{array}$ & $\begin{array}{c}\text { Environmental } \\
\text { Costs } \\
\end{array}$ \\
\hline & \multicolumn{2}{|c|}{ Road only } & \multicolumn{3}{|c|}{$\begin{array}{c}\text { Intermodal } \\
\text { (MoS Bcn-Savona-Livorno) }\end{array}$} \\
\hline Zaragoza-Florence & 1373 & 19.81 & 403 & 793 & 12.83 \\
\hline Madrid-Florence & 1685 & 24.31 & 714 & 793 & 17.32 \\
\hline Seville-Florence & 2077 & 29.97 & 1091 & 793 & 22.76 \\
\hline Barcelona-Florence & 1087 & 15.69 & 94 & 793 & 8.37 \\
\hline Valencia-Florence & 1428 & 20.61 & 443 & 793 & 13.41 \\
\hline Almería-Florence & 1876 & 27.07 & 890 & 793 & 19.86 \\
\hline Vitoria-Florence & 1424 & 20.55 & 625 & 793 & 16.04 \\
\hline Oviedo-Florence & 1705 & 24.60 & 987 & 793 & 21.26 \\
\hline \multirow[t]{2}{*}{ A Coruña-Florence } & 1970 & 28.43 & 1183 & 793 & 24.09 \\
\hline & \multicolumn{2}{|c|}{ Road only } & \multicolumn{3}{|c|}{$\begin{array}{c}\text { Intermodal } \\
\text { (MoS Valencia-Salerno) }\end{array}$} \\
\hline Zaragoza-Salerno & 1884 & 27.19 & 315 & 1372 & 16.69 \\
\hline Madrid-Salerno & 2196 & 31.69 & 355 & 1372 & 17.26 \\
\hline Seville-Salerno & 2588 & 37.34 & 657 & 1372 & 21.62 \\
\hline Barcelona-Salerno & 1598 & 23.06 & 349 & 1372 & 17.18 \\
\hline Valencia-Salerno & 1939 & 27.98 & 0 & 1372 & 12.14 \\
\hline Almería-Salerno & 2387 & 34.44 & 442 & 1372 & 18.52 \\
\hline Vitoria-Salerno & 1936 & 27.94 & 567 & 1372 & 20.32 \\
\hline Oviedo-Salerno & 2216 & 31.98 & 805 & 1372 & 23.76 \\
\hline A Coruña-Salerno & 2481 & 35.80 & 951 & 1372 & 25.87 \\
\hline
\end{tabular}

(a) In the case of routes from Spain to London using the "road only" option, we considered the kilometers (and environmental costs) resulting from using the train in the Eurotunnel. 
Related to the preceding issue, this paper has also addressed the role of decision makers in modal choice in the case of SSS and MoS. Identifying the decision makers determines the target group for possible interventions or stimuli that might motivate the use of intermodal transportation for environmental or other reasons. In the case of semi-trailers-Ro-Ro operations are the main focus of MoS - and in a context such as that of Spain — predominantly small and medium-sized enterprises that generally subcontract transport services, and with an increasing number of large companies also outsourcing this activity to logistics service suppliers/road haulers - the modal choice decision is made by these transport operators. This is even evident if we bear in mind that logistics service suppliers/road haulers coordinate the transport chain where intermodal operations involve semi-trailers. Nevertheless, this does not exclude the significant role that can be played by shippers. As their environmental strategy becomes more proactive, they can play a key role in stimulating and urging, if not obliging, transport operators to adapt their structures and use intermodal transport chains. In any case, both agents need information about the environmental impacts of the different transport modes regarding the different routes used.

Furthermore, and as the most important contribution of our study, we have compared the environmental costs of road haulage and the maritime intermodal option for 72 different routes (nine for each MoS assessed), considering three departure cities for each of the three main Spanish transport corridors. For this comparative analysis we have applied the values the European Commission provides to calculate external costs for the Marco Polo freight transport project proposals (call 2013). The results indicate that in two thirds of cases (48 out of 72, 66.7\%) the maritime intermodal option involves lower environmental costs; but, importantly, there are also 24 routes where the road option is environmentally preferable. In a few of these 24 routes, the higher environmental costs of the intermodal option are simply due to greater distances (in $\mathrm{km}$ ) than those of the "road only" route. However, most of the cases where the intermodal option is not environmentally preferable are found in medium-long distance Ro-Pax services (particularly routes linking Santander and Bilbao with Portsmouth), where passenger transport is prioritized and faster speeds are required to keep transit times down to an acceptable level. Although combining the two segments - passengers and freight - can favor the viability of certain MoS, the different transit time requirements (higher in the case of passengers) might make this option less environmentally preferable for freight transport.

One of the theoretical advantages the literature attributes to SSS over road freight transport is lower fuel consumption, which depends on relatively low speed. However, environmental benefits associated to low fuel consumption might be erased when high-speed vessels are used (the case on lines primarily devoted to passenger transport). Our results show that comparative analysis between modes must be made for each specific route. Moreover, our findings, and also those of other recent studies [18,19], suggest that the assumption that SSS - and MoS - are more environmental friendly per se than road transport can be questioned. Consequently, the air pollution argument for the development of MoS and for promoting the modal shift must be used carefully.

It should be noted that the innovations and improvements in the last decade designed to reduce environment impacts for the road transport industry have no equivalent in the field of maritime transport. This fact, together with the use of high-performance ships on the MoS in an attempt to offer levels of service similar to those of road transport - with a notable increase in fuel consumption - have reduced the traditional advantages of sea transportation in environmental terms, and are in some cases 
a worse option, as we have found in this study. From the shipping industry's perspective, it is therefore necessary to enhance energy efficiency (lower fuel consumption, use of cleaner fuels, etc.) with the aim of preserving its traditional advantages in the environmental dimension.

Although we have used the Marco Polo calculator coefficients in our comparative analysis, we have also emphasized how using different tools to compare the environmental costs of transport modes can generate different results. There is no general agreement on how to quantify external cost for each transport mode. Other calculation methodologies have been employed in the literature, using different values regarding the environmental costs per ton/kilometer associated to each mode. Researchers and also decision makers need clear references on the environmental costs of each mode and, in this sense, greater efforts are required to remedy existing shortcomings.

As a limitation of the study, although the coefficients used by the Marco Polo calculator are considered adequate for comparative purposes, the values of the environmental costs could be refined to consider a number of specific characteristics for each specific transport service considered. However, these specific characteristics may be numerous and, beyond the basic data on the ship, such as engine power; accurate quantitative evaluations require much more information: the loading factors of the ship, and of the units loaded (on certain routes with traffic imbalances the number of empty returns can be considerable) to avoid the "double load factor problem"; the percentage of accompanied and unaccompanied trucks (the latter take up less space and allow more units to be loaded); Ro-Pax services meeting the challenge of allocating emissions and energy use to passengers, cars and trucks (different allocation techniques can be used and the outputs may differ); taking into account the seasonality of passenger traffic or that the line might be operated by different ships; trucks have different type of engines, which complicate the modal comparison, etc. This could be feasible in studies analyzing a specific shipping line in depth, but not in studies such as this one that aim to provide a more general picture of the different MoS in the Spanish context.

\section{Acknowledgments}

This study has benefited from the funding of the Universitat Jaume I (research project P1 1B2012-50).

\section{Conflicts of Interest}

The author declares no conflict of interest.

\section{References}

1. Kahn-Ribeiro, S.; Kobayashi, S.; Beuthe, M. Transport and Its Infrastructure. In Climate Change 2007: Mitigation; Metz, B., Davidson, O.R., Bosch, P.R., Dave, R., Meyer, L.A., Eds.; CUP: Cambridge, UK, 2007.

2. Wolf, C.; Seuring, S. Environmental impacts as buying criteria for third party logistical services. Int. J. Phys. Distrib. Logist. Manag. 2010, 40, 84-102.

3. Lieb, K.J.; Lieb, R.C. Environmental sustainability in the third-party logistics (3PL) industry. Int. J. Phys. Distrib. Logist. Manag. 2010, 40, 524-533. 
4. Schwanen, T.; Banister, D.; Anable, J. Scientific research about climate change mitigation in transport: A critical review. Transp. Res. A Pol. Policy Pract. 2011, 45, 993-1006.

5. Björklund, M. Influence from the business environment on environmental purchasing-Drivers and hinders of purchasing green transportation services. J. Purch. Supply Manag. 2011, 17, 11-22.

6. Oberhofer, P.; Fürst, E. Sustainable development in the transport sector: Influencing environmental behavior and performance. Bus. Strategy Environ. 2013, 22, 374-389.

7. Wu, H.; Dunn, S. Environmentally responsible logistics systems. Int. J. Phys. Distrib. Logist. Manag. 1995, 25, 20-38.

8. Abukhader, S.; Jönson, G. Logistics and the environment: Is it an established subject? Int. J. Logist. Res. Appl. 2004, 7, 137-149.

9. Rondinelly, D.; Berry, M. Multimodal transportation, logistics and the environment. Managing interactions in a global economy. Eur. Manag. J. 2000, 18, 398-410.

10. Eng-Larsson, F.; Kohn, C. Modal shift for greener logistics-The shipper perspective. Int. J. Phys. Distrib. Logist. Manag. 2012, 42, 36-59.

11. Bergantino, A.A.; Bolis, S. Monetary values of transport service attributes: Land vs. maritime Ro-Ro transport. An application using adaptive stated preferences. Marit. Policy Manag. 2008, 35, 159-174.

12. Feo, M.; Espino, R.; García, L. An stated preference analysis of Spain freight forwarders modal choice on the south-west Europe motorway of the sea. Transp. Policy 2011, 18, 60-67.

13. Commission of the European Communities. White Paper-European Transport Policy for 2010: Time to Decide; Commission of the European Communities: Brussels, Belgium, 2001.

14. Lammgård, C. Environmental Perspectives on Marketing of Freight Transports; The Intermodal Road-rail Case, BAS Publishing: Goteborg, Sweden, 2007.

15. McKinnon, A. The potential of economic incentives to reduce $\mathrm{CO}_{2}$ emissions from goods transport. In Proceedings of the 1st International Transport Forum on "Transport Energy: The Challenge of Climate Change", Leipzig, Germany, 28-30 May 2008.

16. Medda, F.; Trujillo, L. Short-sea shipping: An analysis of its determinants. Marit. Policy Manag. 2010, 37, 285-303.

17. Commission of the European Communities. White Paper-Roadmap to a Single European Transport Area-Towards a Competitive and Resource Efficient Transport System; Commission of the European Communities: Brussels, Belgium, 2011.

18. Hjelle, H.M. Short sea shipping's green label at risk. Transp. Rev. 2010, 30, 617-640.

19. Vanherle, K.; Delhaye, E. Road versus short sea shipping: Comparing emissions and external costs. In Proceedings of the International Association of Maritime Economists, Lisbon, Portugal, 7-9 July 2010.

20. Stead, D. Mid-term review of the European Comission's 2001 Transport White Paper. Eur. J. Transp. Infrastruct. 2006, 6, 365-370.

21. Hilmola, O.-H. The competitiveness of short sea shipping taking into account environmental, infrastructure and oil costs. A Case study of the Tallinn-Warsaw Route. Int. J. Ocean Syst. Manag. 2012, 1, 384-394.

22. Martinsen, U.; Björklund, M. Matches and gaps in the green logistics market. Int. J. Phys. Distrib. Logist. Manag. 2012, 42, 562-583. 
23. Macharis, C.; Bontekoning, Y.M. Opportunities for OR in intermodal freight transport research: A review. Eur. J. Oper. Res. 2004, 153, 400-416.

24. Bontekoning, Y.M.; Macharis, C.; Trip, J.J. A review of intermodal rail-truck freight transport literature. Transp. Res. A Policy Pract. 2004, 38, 1-34.

25. Caris, A.; Macharis, C.; Janssens, G.K. Planning problems in intermodal freight transport: Accomplishments and prospects. Transp. Plan. Technol. 2008, 31, 277-302.

26. Macharis, C.; Caris, A.; Jourquin, B.; Pekin, E. A decision support framework for intermodal transport policy. Eur. Transp. Res. 2011, 3, 167-178.

27. Jugovic, A.; Debelic, B.; Brdar, M. Short sea shipping in Europe factor of the sustainable development transport system of Croatia. Pomor. Sci. J. Marit. Res. 2011, 25, 109-124.

28. Martinsen, U.; Huge-Brodin, M. Greening the offerings of logistics service providers. In Proceedings of the 22nd Annual NOFOMA Conference: Logistics \& Supply Chain Management in a Globalised Economy, University of Southern Denmark, Kolding, Denmark, 10-11 June 2010; Stentoft Arlbjorn, J., Ed.; pp. 969-984.

29. Mulligan, R.F.; Lombardo, G.A. Short sea shipping-Alleviating the environmental impact of economic growth. WMU J. Marit. Aff. 2006, 5, 181-194.

30. Leinbach, T.R.; Capineri, C. Globalized Freight Transport: Intermodality, E-commerce, Logistics, and Sustainability (Transports Economics, Management and Policy); Edward Elgar Publishing: Northampton, MA, USA, 2007.

31. Denisis, A. An Economic Feasibility Study of Short Sea Shipping Including the Estimation of Externalities with Fuzzy Logic. Ph.D. Thesis, University of Michigan, Ann Arbor, MI, USA, 2009.

32. Kapros, S.; Panou, C. Coastal shipping and intermodality in Greece: The weak link, Maritime. Transport 2007, 21, 323-342.

33. Perakis, A.N.; Denisis, A. A Survey of short sea shipping and its prospects in the USA. Marit. Policy Manag. 2008, 35, 591-614.

34. López-Navarro, M.A.; Moliner, M.A.; Rodríguez, R.M. Long-term orientation of international road transport firms in their relationships with shipping companies: The case of short sea shipping. Transp. J. 2011, 50, 346-369.

35. López-Navarro, M.A. The effect of shared planning by road transport firms and shipping companies on performance in the intermodal transport chain: The case of Ro-Ro short sea shipping. Eur. J. Transp. Infrastruct. 2013, 13, 39-55.

36. European Commission. The EU's Freight Transport Agenda: Boosting the Efficiency, Integration and Sustainability of Freight Transport in Europe. Report on the Motorways of the Sea: State of Play and Consultation; European Commission: Brussels, Belgium, 2007.

37. Parantainen, J.; Meriläinen, A. The Baltic Sea motorway-Recent development and outlook for the future. J. Marit. Res. 2007, 4, 21-30.

38. Baird, A.J. The economics of motorways of the sea. Marit. Policy Manag. 2007, 34, 278-310.

39. Paixão, A. Motorways of the sea port requirements: The viewpoint of port authorities. Int. J. Logist. Res. Appl. 2008, 11, 279-294.

40. Valente de Oliveira, L. Annual Report. Fostering Seamless Transport in the European Union: Motorways of the Sea in the European Logistic Chain; European Commission: Brussels, Belgium, 2008. 
41. Preparing for Motorways of the Sea. Available online: http://ec.europa.eu/transport/maritime/ motorways_sea/preparing_en.htm (accessed on 8 February 2014).

42. Gesé, X.; Baird, A.J. European Motorways of the sea: Lessons from the Spanish experience. Int. J. Ocean Syst. Manag. 2012, 1, 395-419.

43. Beskovnik, B. Importance of short sea shipping and sea motorways in the European and Slovenian Transport Policy. Pomor. Sci. J. Marit. Res. 2006, 20, 23-35.

44. Hallock, S.; Wilson, D. Urban freight transport: The short sea shipping alternative for Melbourne. In Proceedings of the 32nd Australian Transport Research Forum, Auckland, New Zealand, 29 September-1 October 2009.

45. Paixão, A.; Marlow, P. Strengths and weaknesses of short sea shipping. Mar. Policy 2002, 26, $167-178$.

46. Baindur, D.; Viegas, J. Challenges to implementing motorways of the sea concept-lessons from the past. Marit. Policy Manag. 2011, 38, 673-690.

47. Baindur, D.; Viegas, J. Success factors for developing viable motorways of the sea projects in Europe. Logist. Res. 2012, 4, 137-145.

48. Gesé, X.; Baird, A.J. Motorways of the sea policy in Europe. Marit. Policy Manag. 2013, 40, 10-26.

49. Bergantino, A.S.; Bolis, S. An analysis of maritime Ro-Ro freight transport service attributes through adaptative stated preferences: An application to a sample of freight forwarders. Eur. Transp. 2004, 25-26, 33-51.

50. Brooks, M.R.; Trifts, V. Short sea shipping in North America: Understanding the requirements of Atlantic Canadian shippers. Marit. Policy Manag. 2008, 35, 145-158.

51. Garcia, L.; Feo, M. European common transport policy and short-sea shipping: Empirical evidence based on modal choice models. Transp. Rev. 2009, 29, 239-259.

52. Pérez-Mesa, J.C.; Céspedes, J.J.; Salinas, J.A. Feasibility study for a Motorway of the Sea (MoS) between Spain and France: Application to the transportation of perishable cargo. Transp. Rev. 2010, 30, 451-471.

53. Puckett, S.M.; Hensher, D.A.; Brooks, M.R.; Trifts, V. Preferences for alternative short sea shipping opportunities. Transp. Res. E 2011, 47, 182-189.

54. Mange, E. Short sea shipping cost benefit analysis. In Proceedings of the European Transport Conference, Association for European Transport, Strasbourg, France, 18-20 September, 2006. Available online: http://stuff.mit.edu/afs/athena/course/11/11.951/oldstuff/albacete/Other_Documents/ Europe\%20Transport\%20Conference/freight_and_logistics/short_sea_shipping1378.pdf (accessed on 12 February 2014).

55. European Court of Auditors. Have the Marco Polo Programmes Been Effective in Shifting Traffic off the Road? European Court of Auditors: Luxembourg City, Luxembourg, 2013.

56. López-Navarro, M.A.; Moliner, M.A.; Rodríguez, R.M.; Sánchez, J. Accompanied versus unaccompanied transport in short sea shipping between Spain and Italy: An analysis from transport road firms perspective. Transp. Rev. 2011, 31, 425-444.

57. Woxenius, J.; Bergqvist, R. Comparing maritime containers and semi-trailers in the context of hinterland transport by rail. J. Transp. Geogr. 2011, 19, 680-688. 
58. Schamm, H.J. Governance of multimodal transport chains: A brokerage roles approach. In Proceedings of the Logistics Research Network Annual Conference 2006, Newcastle, UK, 6-8 September 2006.

59. Paixão, A.; Marlow, P. The impact of Trans-European Transport Networks on the development of short sea shipping. Marit. Econ. Logist. 2007, 9, 302-323.

60. Gouvernal, E.; Slack, B.; Franc, P. Short Sea and deep sea shipping markets in France. J. Transp. Geogr. 2010, 18, 97-103.

61. López-Navarro, M.A. Unaccompanied transport as a strategy for international road hauliers in Ro-Ro short sea shipping. Marit. Econ. Logist. 2013, 15, 374-394.

62. Short Sea Promotion Centre Spain transport chain calculator. Available online: simulador.shortsea.es/simulador.aspx (accessed on 12 February 2014).

63. Brons, M.; Christidis, P. External Cost Calculator for Marco Polo Freight Transport Project Proposals, 2013; Report EUR 26021; Joint Research Centre: Brussels, Belgium, 2013.

64. Maibach, M.; Schreyer, C.; Sutter, D.; van Esse, H.P.; Boon, B.H.; Smokers, R.; Schroten, A.; Doll, C.; Pawlowska, B.; Balk, M. Handbook on Estimation of External Costs in the Transport Sector (IMPACT); CE Delft: Delft, The Netherlands, 2008.

65. Proost, S. TREMOVE 2 Service Contract for the Further Development and Application of the TREMOVE Transport Model (TREMOVE); European Commission, Directorate General of the Environment: Brussels, Belgium, 2006.

66. Bickel, P. Developing Harmonised European Approaches for Transport Costing and Project Assessment (HEATCO); Unviersität Stuttgart: Sttutgard, Germany, 2006.

67. Holland, M.; Pye, S.; Watkinss, P.; Droste-Franke, B.; Bickel, P. Damages per Tonne of PM2.5, $\mathrm{NH}_{3}, \mathrm{SO}_{2}, \mathrm{NO}_{x}$, and VOC's of EU25 Member State (excluding Cyprus) and Surrounding Areas. Service Contract for Carrying Out Cost-Benefits Analysis of Air Quality Related Issues, in Particular in the Clean Air For Europe (CAFE) Programme; AEA Technology Environment: Oxfordshire, UK, 2005.

68. EX-TREMIS; TRT Transporti e Territorio. Development of a Reference System of Emissions Factors for Rail, Maritime and Air Transport (EXTREMIS); Study for European Commission, Joint Research Centre: Brussels, Belgium, 2008.

69. Patsia, M.A.; Botzoris, G.N. Reducing environmental costs of freight transport: Proposal for alternative transport routes. In Proceedings of the 1st International Virtual Conference on Intelligent Transportation Systems, Zilina, Slovakia, 26-30 August 2013. Available online: http://www.itransport.sk/archive/?vid=1\&aid=2\&kid=100101-21 (accessed on 12 February 2014).

70. Sea distances online calculator. Available online: sea-distances.com (accessed on 12 February 2014).

(C) 2014 by the author; licensee MDPI, Basel, Switzerland. This article is an open access article distributed under the terms and conditions of the Creative Commons Attribution license (http://creativecommons.org/licenses/by/3.0/). 